\title{
Manipulating School Culture for Effective Leadership
}

\author{
Vuyisile Msila \\ Institute for African Renaissance Studies (IARS), College of Graduate Studies, University of South Africa \\ msilavt@unisa.ac.za
}

\section{Doi:10.5901/mjss.2014.v5n23p1276}

\begin{abstract}
School culture is getting much attention now as school leaders realize that effective schools imply worthy cultures. Leadership concepts such as collegiality, collaboration, shared leadership and participatory leadership will all be impotent when school culture is not conducive to teaching and learning. All conscientious school managers will begin by manipulating the school culture when they want to attain success. This qualitative study focused on three schools as it explored how school culture influences success. The results illustrate that the difference between low and high performing schools might not have to do only with the social class of the learners and their families, but more with the school cultures that prevail. There are several factors which exacerbate school culture and these include teacher unionism, teacher commitment and professional maturity. Effective leaders will be able to lead in the fostering of an effective culture despite potential hindrances. Shared vision is among the crucial factors in ensuring the creation and sustenance of an effective school culture.
\end{abstract}

Keywords: School culture, Positive climate, Shared vision, Teacher commitment, Learner success.

\section{Introduction: Foundation for Effective Schools}

Recent research demonstrates that working with school culture is the first step towards the realization of a working school. Authors in South Africa have referred to underperforming schools as institutions that have anomalies in culture; a breakdown in the culture of learning and teaching (Mathibe, 2007; Msila, 2011). Gun and Caglayan (2013) argue that the culture of a school is a powerful influence on staff behavior and that culture is crucial for any school's success. A number of positive concepts tossed around in school leadership literature include, shared leadership, collaboration and collegiality. But these cannot be realized in schools where a conducive culture is not evident. Successful schools have certain distinguishing qualities. Butucha (2013) contends that to understand the contributing factors to the success of any organization, it is crucial to study their culture. Arguably, underperforming schools fail because of the dwindling of effective organizational culture. In a paper entitled, In search of teacher commitment Msila (In press) argues that culture is among the strong determinants of committed or uncommitted teachers,

The much notable teacher collaboration and collegiality cannot operate in a school where the climate and culture are poor. Various writers mention a number of crucial qualities for a positive culture to be realized. Butucha (2013) for example, highlights unity of purpose as among the most pertinent when trying to foster an effective school culture. This assertion is supported by Msila (2011) who contends that shared vision is important in inculcating an effective school culture. Teachers in schools can never be effective change agents or managers of change when there is no positive culture. Job satisfaction is enhanced by the leader of the school; however, the leader will be incapable when the culture is weak or repugnant.

School culture helps teachers to be professional in their work and be committed to learner achievement. It encompasses goals, vision and direction desired by role players. Siburian (2013) contends that the role of the teachers is pertinent in the attainment of the school's goals and the school covers numerous things that need to get support from the principals as instructional leaders. When school leaders and their staff want to achieve certain goals, they merely want to manifest shared values. Siburian (2013:253) states:

Organizational culture is a crucial factor in the achievement of goals due to the assumption that organizations are made up of a collection of people who work together require that organizational culture can be used as standards of behavior that has been agreed on in the organization. Organizational culture is a reflection of the organization that distinguishes it from other organizations...Every organization has a particular culture which is believed to accelerate the achievement of organizational goals. 
This paper examines three post-apartheid schools in South Africa and explores how they dapple with issues of transformation and school culture. Many schools especially township (historically black African) schools, struggle to achieve the necessary learner achievement. Huge gaps appear to exist between township schools and historically white schools. The main questions asked was: What factors cause some schools to lack an effective school culture?

The sub-question posed was: What can teachers of underperforming schools learn from high performing schools?

\title{
2. Review of Literature
}

Each school is unique and has its own nature, personality and identity: all these form part of culture. When we say a school has improved from what it was, we imply that its culture has changed somehow. As pointed out above, it is culture that determines whether schools will be effective or not. If school leaders need to manipulate anything in their organizations - school culture needs to be at the top. Kaplan and Owings (2013) define school culture as historically transmitted framework of shared assumptions, values, norms and actions. Hoy and Hoy (2006) refer to school culture as the normative adhesive that holds the school as an organization together. According to Hoy and Hoy various characteristics including attitudes, beliefs, values, ceremonies, traditions and myths form part of school culture. Gun and Caglayan (2013) contend that the success or failure of a school is related to the behavior of its individual role-players.

Gun and Caglayan (2013) point out that crucial aspects of school culture include collegial support and collaboration, collaborative leadership and when a school's role-players change the culture of the school- they change the way things are done at that school. School leaders should also understand how school culture becomes part of the change process. Recepoglu (2013) points out that it is school culture that promotes or hinders change in a school. Therefore, effective school leaders will use culture to enhance change. McMaster (2013) writes about a need for school leaders to have an ethical and moral obligation to create a cultural competent school and argues for a need to constantly prepare culture audits. Apart from these cultural audits, McMaster declares that in maximizing the use of culture all members of the school need to be involved; that management needs to bring all members of the school. McMaster (2013:8) writes:

\begin{abstract}
What was missing in the various mechanisms for measuring school culture or inclusion was the transformational activity which could bring members of the school community together in a shared activity to build on newer ideals and values. Through the process of 'moving' together, the inclusive values could be validated and reinforced in the consciousness of community members. These community members represent all the stakeholders in the school- staff, students, parents, volunteers, administrators, indeed, all those who play a part in the life of the school.
\end{abstract}

When a principal uses this s/he can be able to utilize a framework of shared vision, shared action as s/he transforms old assumptions into new positive values for the school. The idea of community involvement Merrett and Merrett (2013) argue that positive school culture can be attained through the use of behavioral approach by frequent use of reinforcements (rewards and punishments) to modify behavior. The modification of this behavior can be attained by focusing on culture. MacNeil, Prater and Busch (2009) argue that educational theorists have reported that the principals' impact on learning is facilitated through culture. Furthermore, they point out that when culture is not congruent to learning the learners' achievement suffers. MacNeil et al. also assert that there are interactions between schooling and culture. School principals can transform the teaching and learning culture of a school. "When an organization has a clear understanding of its purpose, why it exists and what it must do and who it should serve the culture will ensure that things work well" (MacNeil et al. 2009:74).

Among others, principals need to use the complexity of culture to create inclusive schools for learners coming from varying backgrounds. Riehl (2000) underscores the need for school leaders to respond to diversity. Riehl also contends that principals can influence meaning-making in their schools: through the day-to-day management of meanings among organizational role-players; through the mediation of conflict when open contention arises; and through the cognitive task of resolving contradictions within their own ideological perspectives. All this is about influencing culture. Principals who want to shape conducive cultures in their schools will work closely with other role-players. Riehl (2000) cites Cibulka who states that principals need to exercise strong leadership in helping build community power base, by informing the public of educational problems and training community members. The latter is crucial because when school leaders work with community members, they reinforce their power base. 


\section{Research Methodology}

The data in this study was collected through qualitative research methods. The researcher gathered data in three schools which are historically different. In apartheid South Africa these schools served different racial groups. School A/lkamva High School is a historically black African school situated in a township or a historically black area. School B/ Waterfalls High School is a former white school situated in the city. School C/Hillock High School is a former Coloured school and is situated in a historically Coloured residential area. These schools were purposefully selected. In each of the schools seven participants were selected. The participants included the principal, four school management team members, two teachers and one School Governing Body Chairperson. In collecting the data, qualitative research does not control the context but rather to capture the context in its entirety (Brink, 2000). Struwig and Stead (2004) point out that the researcher in qualitative research is part of reality and that the research is not completely objective. These authors also cite Guba and Lincoln who point out that knowledge is based on consensus but can differ according to contextual, political, and cultural factors.

The researcher interviewed all the participants individually over three times in the three months he was in each of the schools. He also visited the schools once weekly for three months to observe what was happening in classrooms, playground, and management as well as staff meetings. During these observations field notes were taken. All the participants were aware of ethical considerations including their rights. They became part of the study after signing the consent forms. After the interviews they were all given transcripts to correct any misinterpretations especially those from Ikamva who used code-switching utilizing both isiXhosa and English during interviews.

\section{Discussion of the Findings}

Although all the participants understood the role of culture in schools some pointed out that they did not always know how to manipulate culture for the betterment of the school. In Ikamva High School, for example, the school managers appeared to believe that they could not change the school culture much because the school has been failing for several years and they maintained that there was not much that they could do to change these circumstances. So desperate the situation at this school that the teachers maintain that to change the culture in the school staff members need much assistance from community, parents and district officials. In Ikamva the teachers concurred that their school lacks delegation, shared leadership and commitment. Whenever the researcher visited the school, the school did not display semblance of a well-run organization. At any time of the day there were learners roaming around the school and some classes would not have any teachers especially after morning interval. The school management in Ikamva has given up the hope of rebuilding the school and teachers stated that they hardly think the culture in the school would every change because the management "is usually railroaded by charlatan teachers". Many teachers are very much politicized and unionized, so much that the principal feels impotent in the face of strong teacher unionism.

The culture is different in Waterfalls where teachers show work ethic at all times. During school hours one is unlikely to see children walking about aimlessly as one would find in Ikamva. The heads of department informed the researcher that only teachers who have free time would be in the staffroom during teaching time. There was also no absenteeism, a factor that was a commonplace in Ikamva. On any given day teachers who would be absent from school at Waterfalls ranged from naught to one whilst at Ikamva it was always from four to seven teachers. The leadership culture in Ikamva appeared to be that of laissez faire approach for teachers appeared to come and go as they pleased. In the three months that the researcher was at Waterfalls there were five student teachers from one local university. These students were welcomed in a culture where they could learn from the teaching practice because they were supported immensely in the school. The culture in Waterfalls is so supportive that developing professionally is immense. The participants in Waterfalls attested to the school's ability to develop teachers.

Hillock displayed a culture that had certain pockets of effectiveness. This school is populated by learners from poor families who have neither social nor cultural capital. Under apartheid the school served the Coloured community although now it is almost $70 \%$ black. Many learners are usually late because they travel long distances to school. School management though always tries to curb the roaming of learners within and outside the school premises. In Hillock there was a level of teacher commitment. Amongst others teachers tried to support the poverty stricken learners with programs such as school feeding scheme, extra classes on some Saturdays and certain afternoons after school. The principal also tries to instil a sense of collaboration although he states that "it is not always easy". The principal cites the politicization and unionization of teachers as having a major impact on many school decisions as well as management. Sometimes teachers do not want to commit to certain decisions at school until they hear from their unions and this includes the hiring of teachers. "Teachers may dispute the hiring of teachers until given a green light by their unions". The principal at Hillock 
though says that his strong union involvement in the past has enabled him to regulate teacher union activities as he gives union members to be part of the school's management structures. All the three SGB members from the schools supported the position of the teachers regarding the cultures in their schools. The Ikamva SGB chairperson though emphasized that she did not think the school would improve soon because "the culture in the school was pathetic". This chairperson stated that the culture in the school was very discouraging to the school management and the children's families. She also blamed teachers for this culture because they lacked the professional work ethic.

Below, the discussion is divided into three themes; teacher unionism, teacher commitment and culture.

\subsection{Teacher unionism}

Teacher unionism is characterized by controversy in South Africa. It was interesting to hear the principals talk about unionism in their schools. There are quite a number of factors when unions go on strike. Smit (2013) writes about how the 2010 teacher strike in South Africa by members of the largest teachers' union the South African Democratic Teachers Union (SADTU) was "characterized by intimidation, violence, vandalism and general unlawful conduct by teachers" (Smit 2013:347). Others have argued though that teachers unions like all unions have a democratic right to strike. However, when teachers strike, children suffer. Some have argued that unions such as SADTU negatively impact on school leaders through strikes (Patillo, 2012). However, sometimes people forget the historical foundations of SADTU as a union. Having been a union that fought apartheid and oppression- it appears hard for this union to move away from this identity. The teachers' politicization is a result of the history of South Africa. Patillo (2012) also argues that leadership is the factor that has most impact on whether or not a township school culture has corruption in the form of teacher absenteeism, tardiness and general lack of commitment to effective teaching. Furthermore, Patillo (2012:19) argues, "What makes effective school leaders different from ineffective leaders is that they have more of a commitment to eliminating a culture of quiet corruption in their schools and doing whatever it takes to make students succeed".

The Waterfalls principal stated that she never has problems with his staff concerning union participation. She says her school, like various other neighbouring schools "do not sacrifice school time to run union activities". She says she has witnessed so many times township schools being closed because of union programs of action. She says whilst she "does not have members from the more radical SADTU" (only two members in her school), "even if there was, I would still stamp my foot down. School time is school time". She says the success of her school is mainly due to teachers "sacrificing their all for the learners". In Waterfalls there are mainly South African Teachers Union (SATU) members. The principal says that there is an understanding in the school that union programs should never disrupt school program. In her school the union's site committee members work closely with management and in staff meeting all unions are accorded a chance to state their case whenever necessary. The collaboration that happens in Waterfalls is absent in Ikamva which shall now be discussed.

As in Waterfalls there are two unions in Ikamva and these are SADTU and the National Professional Teachers Organization of South Africa (NAPTOSA). SADTU has 31 members out of a total staff of 42. One NAPTOSA teacher still recalls how she was intimidated by two SADTU colleagues when she wanted to go to work in the 2010 strike. In fact, NAPTOSA members concur that whenever there are labour disputes where SADTU has decided to engage in a program of action everyone is compelled to be part of the action. The principal in lkamva pointed out that the union sometimes interferes with the management of the school. Frequently, union representatives would inform him of some union meetings during school time. He also stated that he found it difficult to discipline teachers who have done misdemeanours because they would seek union protection even when they were on the wrong. Furthermore, he argues that his teachers would sometimes disregard his decisions in his schools to hear what union leadership would tell them instead.

The majority of participants again concurred that teacher organizations are not doing as much as they should to bolster the professional craft of teachers. Many asserted that many schools continue to experience poor culture of teaching and learning despite the strong presence of the unions. Pratte and Rury (1991) write about the need for the enhancement of teachers and their professional craft. They describe a craft as "more than skills and knowledge. It also entails sensibility, an awareness of one's abilities and a commitment to developing them in the context of day-to-day performance (Pratte \& Rury 1991: 64). The findings in Ikamva are consistent with my findings in an earlier study which show that in some schools where there are no strong union operations there was relatively more success in learning and teaching (Msila, 2014). The principals reported that while there were problems, many of these did not emanate from power wrangling between unions and school management. However, in schools where teacher unions were stronger, teachers tended to direct their power in competing among themselves while trying to gather more members for their own unions. Yet within this mire of the battle for power, teacher unions neglect the need to collaborate with one another as they embrace the educational changes. Johnson (2007: 217) points out that educators have to collaborate with teacher 
unions that perceive teachers as public intellectuals and view urban schools as sites of educational and social transformation. The culture inculcated by unions in numerous schools over decades has been militancy vs professionalism of teachers. In many dysfunctional schools union culture worsens the school progress.

In Hillock High School the principal tends to be high handed when it comes to union activity. He says that he is usually unpopular when it comes to labor.

\subsection{Teacher commitment}

Without committed teachers the school culture becomes impoverished. School culture is enhanced by committed teachers who put their children first. Mart (2013) points out that teachers who are highly committed work harder, and are attached to their schools as they make sure that learners succeed. Furthermore, Mart (2013) contends:

Teachers with high level of commitment will be more loyal to schools where they work; similarly, teachers with high level of commitment will contribute students' achievement effectively. Commitment is praiseworthy because it facilitate learning. If good working conditions are provided for committed teachers, effectiveness of the educational organization that will lead to positive consequences for the schools and students will enhance.

Razak, Darmawan and Keeves (2010) point out that committed teachers have strong psychological ties to their schools, to their learners and to their subject areas. Commitment needs to be part of culture. In Ikamva High the teachers stated that they were always stressed by a number of things at school including

Many dysfunctional schools might be failing because teachers have lost the commitment to their profession. Milner and Khoza (2008) contend that aspects such as teacher stress, school climate are pertinent when one looks at teacher commitment. Erawan (2010) draws a close relationship between teacher efficacy and teacher commitment. Furthermore, Erawan (2010) argues that self-efficacious teachers will be more likely to plan appropriate activities, persist with learners who are experiencing difficulties and try and find appropriate teaching material. When the post-apartheid system was introduced in South Africa some critics argued that it would fail without teacher commitment and teacher involvement. Arguably, this is true as one sees many schools failing to achieve a certain level of learner success. Moreover, when the learners' performance wanes, it is likely for teachers to highlight various reasons for low performance in their failing schools. Parents who do not cooperate, children who are not goal-focused, under-resourced schools and principals who have no vision are among reasons cited for underperformance in schools. Conscientious and committed teachers will strive for better performance in these areas. It should be clear though that apart from learner results, school performance is influenced by a number of aspects; the families' socio-economic status, parental involvement, resources are among these (Msila, 2011). Yet when people talk about reasons why schools fail, they overlook aspects such as commitment. It would be naive to look at minimal resources as the main problem, but it would be equally irresponsible to perceive teachers as the only cause of under-performance. However, Huberman (1993) point out that teacher commitment is among the critical factors in the success and future of education. Throughout a teacher's life, commitment is influenced by various factors.

Commitment is what needs to come from a team. As organizations become more dynamic they would require committed teams to function. Hulpia et al. (2012) point out that leadership has become more than a role; it is a social process that requires leadership from team members as well as from the team leader. Committed teams will remove the role of the principal as sole leader. Many authors have since argued for distributed leadership as an aspect that can enhance commitment of the organization. Harris (2008) writes about the benefits of distributed leadership by highlighting that it has positive effects on teachers' self-efficacy, morale which can have an impact to teacher commitment. One of the schools I visited for the Advanced Certificate in Education School Leadership and Management research in the province of KwaZulu-Natal, (South Africa) had a very effective principal who is always hands on. However, he had a tendency to kill teacher morale and commitment by refusing to give other teachers a chance to lead; there was less delegation in his school. In that study, one teacher raised his concerns when he contended how the principal has built the poor school through a number of creative projects. However, he felt that the principal needed to trust teachers more and that he should delegate more responsibilities to fellow staff members. Bush and Glover (2003) also cite Harris (2002) and Leithwood (2001) who both advocate distributed leadership as an alternative to top-down leadership models. Furthermore, Bush and Glover argue that participative leadership may sometimes be conceptualized as distributed as organizations ensure that collaborative decision-making are preferred to single person decision-making.

Mart (2013) maintains that there is a need for teachers to be passionate about teaching if they are to be committed to the school and the learning by students. Furthermore, Mart cites Fried (2001) who explains the following as strong 
connection between passionate teaching and quality student learning:

1. If students know that teachers get immersed in their subjects and sets high standards for students, they take their studies more seriously. At this point, teaching ceases to be a job done by force, and turns into an inspiration for students;

2. There is little chance of building a relationship based on respect and trust between teacher and student unless a collaborative learning environment and willingness to take risks are not created; and

3. Students will not have motivation to learn as long as they do not have clear idea of how to apply things they have learnt to their own lives.

Teachers who believe in their jobs and committed in instilling change will engender these values. The importance of commitment was also found crucial in a study by Bush et al. (2009). Linked to this was the aspect of school culture.

\subsection{School culture}

Bush et al (2009) write about the importance of culture in schools in determining leadership. Whilst studying the impact of the Advanced Certificate in Education - School Management and Leadership (ACE-SML), they found out that culture is among the determinants of effective and ineffective schools. The concept, culture, is one of the two important words in organizational behavior, the other being climate. In schools, these determine the morale of teachers, the interest of parents and community and most importantly, they impact on learner achievement. These however, can be misunderstood terms. Gruenert (2008) points out that school leaders who want to address morale in their organizations must know the distinction between culture and climate. Furthermore, this author emphasizes that teachers need to know the difference if they want to be more precise in their diagnoses and treatment of the two. This implies that it would be difficult to improve schools without understanding the differences and similarities between these terms. Gruenert also points out that climate is the main leverage point for any culture, which means that if school leaders want to shape a new culture; they should start with an assessment of the climate.

One of the most crucial aspects in today's organizations is shared leadership. Effective innovation in schools needs shared vision and shared perceptions. It is impossible to cherish the ideals of commitment without identifying with the goals and values that others share. All these will also not be possible without the relevant school culture. Whenever an individual matures into an established culture without questioning its morality or reigning common sense as person has betrayed his or her human freedom by behaving like an object by cultivating what Satre refers to as bad faith. Sometimes, consciously or unconsciously people would excuse their actions by raising upbringing for example, again this is an escape from responsibility. Our schools need teachers who reflect and imbue this responsibility and equanimity. Very few schools will have a strong culture when teachers do not show any responsibility and freedom.

Culture influences the people's social behaviors and interests and the way they interact with others (Zhu, Devos \& $\mathrm{Li}, 2011)$. The majority of schools do not perform well because of the absence of the effective school culture. Scholars mention a number of aspects such as ineffective school leadership, community in which the school is built, the noninvolvement of other role-players. Yet all these can be referred to as sub-sets of culture. Zhu et al. (2011: 320) contend:

School culture is closely related to the healthy and sustainable development of a school, the development and well-being of the school members, and objectives of the school and education. An important dimension of school culture is the multiple interactions among groups and individuals.

\subsection{Lack of vision}

The understanding of the concept "vision", its presence and its application are among the most important in determining the direction and culture of any school. An effective vision permeates through all sections of the organization. When the vision is clear and effective the school will have satisfied community, parents and learners. It is unlikely that a culture of any school will be conducive to learning and teaching when there is no vision. Strong unionism will overcome the management in schools when there is no vision that guides its ethos. Kaplan and Owings (2013) wise principals employ school wide vision in guiding their schools to success. Among others this school wide vision includes values (for positive changes), a map (for a sense of certainty and clearly marked path) and a challenge (a vision pushes people to transcend the status quo). Some authors prefer to speak of a shared vision which implies that the vision is shared by various other school role-players rather than the principal only. McMaster (2013) contends that collaboration during the reculturing process of a school is important hence the need for a shared vision. He also points out that shared vision becomes a voice for diverse members of the school community. It was however, interesting to see how vision was utilized in the schools under study. 
All the schools used vision in different ways. In Ikamva High School the teachers as well as the principal concurred that no vision guided the school. Although there is one emblazoned on a photo frame in the staff room, this was not applied at all. As demonstrated above, the school management has a laissez-faire approach with the teachers accusing the management of incompetence whilst the school management saw the teachers as a hindrance to school growth. The absence of a vision in the school means that there is no culture of creating and implementing a working vision. Every teacher or cliques have created their own values that guide them in the school. Some of these are not necessarily good values. As one teacher put it:

The parents here do not care, the principal and his management does not care. Why should we care? That is what guides us here; we will always follow the example set by those above. The principal is hardly here hence you will find much absenteeism among teachers as well as learners. Nothing really guides us here. We are not at all like other schools you might have been to.

Ikamva High has no sense of direction and teachers and learners move in different directions. People choose any paths that they think lead to where they will be comfortable. The school has no shared universal values and the confusion manifests itself in learner results and staff morale. Elbot and Fulton (2008) aptly put it as if they refer to lkamva High situation:

Students thrive when they are immersed in an environment defined by shared universal values. Many students attend schools where values and expectations differ from classroom to classroom and hallway to hallway. This can be confusing to students and demoralizing to staff, who feel undermined by their colleagues. Without consensus on values, students learn to respond to the values and expectations of each individual teacher but do not develop an affinity for shared school values, since there appear to be none.

The lack of vision in Ikamva made them not to own the school. There were no values that bound them together. The principal struggled to maintain any culture of driving the school forward because there was no vision at all. A vision binds people together and makes them work as a team towards a common goal.

Hillock high School was different from Ikamva because the principal did have a vision which he always talked about but he failed to sell this to his teachers. The principal had a number of goals for his school. He was aware where he wanted it to be in five to ten years however, he did not share this with the entire staff. Aspects such as absence of delegation demonstrated that the principal did not believe much in his teachers. He believed that the school can only thrive if he ensures that he is hands-on on everything that happens within the school. In his quest for excellence the principal does not share even the most crucial of aspects in the school and the vision is one of these. Work places need a collective attitude among all employees. Leaders can be good but if they do not share their good qualities, their leadership comes to nought. In talking about visionary leaders Fink (2005) makes a contrast between two great leaders in history; Winston Churchill and Adolf Hitler. Churchill developed a shared vision and this created common values amongst his followers. Yet Hitler who was a charismatic leader embodied the vision in their person, he believed only in his leadership; that his country would be nothing without him. This is exactly what happened to this charismatic principal in Hillock High. He had good plans that he still needed to share with the entire staff but the problem was trust.

Teachers in Hillock were aware of this. Many of them praised their principal but did not leave out his main flaws. Ironically the principals thought he was doing all what he was doing including his selfishness to the good of the entire school. For a vision to come into fruition group members should internalize it and believe in it. No organization will thrive without this basic tenet of a vision. Moreover, positive cultures will be shaped by a vision that is understood by all those in the organization. The pride in an organization such as a school can only be sustained when there is a culture of cherishing the same vision. Schools fail because teachers do not know or do not understand the vision of their schools.

In Waterfalls High the principal and her management have engendered a culture that ensures superb performance by learners and teachers. The principal used a shared vision with her management, teachers and parents. The learners followed a culture that was supported by a meaningful and clear vision. Although the teachers also stated that like the principal in Hillock, there were times that their principal would not delegate they maintained that she was the right leader for the school. For a number of years now the school's results reflected the work of dedicated staff that attributed their success to their visionary principal who shared her vision with the school's community. The teachers also reiterated that their school's vision is also supported by other important characteristics such as trust, loyalty, morality, compassion and sharing. The teachers also referred to their school as an institution with a well-articulated culture and a vision that is communicated from administration personnel to teachers. Effective school leaders help in creating the desirable culture based on a sound vision. Ramsey (2008) talks of the need to build an inviting school personality although he says some schools can have multiple personalities. The school personality in Ikamva above shows a school personality that suffers from a number of flaws in such a way that school management struggles. The school vision should bring forth a school personality that reflects a conducive culture for teaching, for learning and success. Schools with an effective culture will 
also strive to close the gap between children who come from different families.

\section{Conclusion}

The study has demonstrated that there are factors that are crucial in building schools with a positive working culture. Schools will always have varying personalities but there are universal factors necessary to ensure that school principals do lead successful schools. The discussions here have also underscored the need for teacher commitment, a sound vision as well as collaborative teacher unionism. When these factors are absent schools will not have desirable cultures that would be congruent to school management that seeks to attain success. These are sometimes the main challenges to school managers in many South African schools and here we have seen how effective schools respond to these. Many underperforming schools such as Ikamva High in this study, lack the strategies to deal with these factors and this has a huge negative impact upon the success of such schools. Underperforming schools lack numerous features found in high performing schools. School managers in these schools struggle to create invitational schools with a healthy climate. When management is always under strain, learners' success can hardly be achieved. Conscientious school leaders will intentionally mould their schools to have working, positive cultures that support quality education.

\section{References}

Brink, H. (2000). Fundamentals of research methodology for health care professionals. Cape Town: Juta.

Bush, T., \& D., Glover, (2003). School leadership: Concepts and Evidence. Reading: National

College for School Leadership.[Online] Available: www.ncsl.org.uk/literaturereviews. (July 30, 2014).

Bush, T., Duku, N., Glover, D., Kiggundu, E., Kola, S., Msila, V., \& Moorosi, P. (2009).

External evaluation research report of the Advanced Certificate in Education: School Leadership and Management. Pretoria: Department of Education/Zenex Foundation.

Butucha, Q. (2013). Gender and School type Differences in Self-efficacy in Teaching, Sky Journal Of Education Research 1(14), 23-31.

Elbot, C.F., \& Fulton, D. (2008). Building an intentional school culture: Excellence in academics and character. Thousand Oaks: Corwin Press.

Erawan, P. (2010). A Comparison of Teaching Efficacy, Commitment to Teaching Profession and Satisfaction with Program Effectiveness of Teacher students under the 5 Year-Program

Curriculum and those under the 4+1 Year Program Curriculum. European Journal of Social Sciences 14 (2), 250- 261.

Fink, D. 2005. Leadership for mortals: Developing and sustaining leaders of learning. London: Paul Chapman Publishing.

Gruenert, S. (2008). School Culture, School Climate: They are not the same thing. Principal, 87(4), 56-59.

Gun, B., \& Caglayan, E. (2013). Implications from the diagnosis of a school culture at a higher education institution. Turkish Online Journal of Qualitative Inquiry 4(1), 47-59.

Harris, A. (2008). Distributed School Leadership: Developing Tomorrow's leaders. New York: Routledge.

Hoy, A.W., \& Hoy, W.K. (2006). Instructional leadership: A research based guide learning in School. Boston: Allyn and Bacon.

Huberman, M. (1993). The Lives of Teachers (J. Neufeld, transl). London: Cassel Villiers House.

Hulpia, H., Devos, G., Rosseel, Y., \& Vlerick, P. (2012). Dimensions of distributed leadership and the impact on teachers' organizational commitment: A study in secondary education. Journal of Applied Social Psychology, 42 (7), 1745-1784.

Kaplan, L., \& Owings, W. (2013). Culture Re-boot: Reinvigorating School Culture to improve Student Outcomes. Corwin: California.

MacNeil, A.J., Prater, D.L., \& Busch, S. (2009). The effects of school culture and climate on student achievement. International Journal of Leadership in Education: Theory and Practice 12(1), 73-84.

Mart, C.T. (2012). A passionate teacher: Teacher commitment and dedication to Student Learning. International Journal of Academic Research in Progressive Education and Development 2(1), 437- 442.

Mathibe, I. (2007). The professional development of school principals. South African Journal of Education, 27(3), 523-540.

McMaster, C. (2013). Building inclusion from the ground Up: A Review of Whole School re-culturing programs for sustaining inclusive change. International Journal of Whole Schooling 9(2), 1-24.

Merrett, A., \& Merrett, L. (2013). The use of reward systems to improve behavior and attainment in schools. British Psychological Society.

Milner, K., \& Khoza, H. (2008). A comparison of Teacher Stress and School Climate across Schools with different Matric Success Rates. South African Journal of Education 28(2), 155-173.

Msila, V. (2011). School management and the struggle for better schools. Africa Education Review 8(3), 434-449.

Msila, V. (2014). Teacher unionism, school management and leadership: a study of (Eastern Cape) schools in South Africa. Education, Management, Administration and Leadership 42(2), 259- 274.

Msila, V. (In Press). In search of a liberating practice: Leadership, teacher commitment and the struggle for effective schools. Sylwan.

Pattillo, K.M. (2012). Quest corruption: Teachers unions and leadership in South African township schools. An unpublished Bachelor of Arts Honors thesis. Connecticut: Wesleyan University.

Pratte, R., \& Rury, J.L. (1991). Teachers, professionalism and craft. Teachers College Record 93, 59-72. 
Ramsey, R.D. (2008). Don't teach the canaries not to sing: Creating a school culture that boosts Achievement. Thousand Oaks: Corwin Press.

Razak, N.A., Darmawan, I.G.N., \& Keeves, J.P. (2010). The influence of culture on teacher Commitment. Social Psychology of Education, 13 (2), 185-205.

Recepoglu, E. (2013). The significance of assumptions underlying school culture in the process of change. International Journal of Educational Research and Technology, 4(2), 43-48.

Riehl, C.J. (2000). The principal's role in creating inclusive schools for diverse students: A review of normative, empirical, and critical literature on the practice of educational administration. Review of Educational Research, 70 (1), 55-81.

Siburian, T. (2013). The effect of Interpersonal Communication, Organizational Culture, Job satisfaction, and Achievement Motivation to Organizational Commitment of State High School

Teacher in the District Humbang Hasundutan, North Sumatera, Indonesia. International Journal of humanities and Social Science 3(12), 247-264.

Smit, M. (2013). Compatibility of democracy and learner discipline in South African schools. De Jure, 345-365.

Struwig, F.W., \& Stead, G.B. (2004). Planning, designing and reporting research. Cape Town: Pearson.

Zhu, C., Devos, G., \& Li, Y. (2011). Teacher perceptions of school culture and their organizational commitment and well-being in a Chinese school. Asia Pacific Education, 12, 319-328. 